\title{
TACIKLING ISSUES OF GLOBAL CONCERN BY REVISITING THE JUSTIFICATIONS FOR STATE APPROACHES TO GOVERNANCE
}

\begin{abstract}
Issues of global concern typically arise where there is a limited commitment to accountable governance. This paper argues that there has been an evolution in the state function. This evolution has made it possible to envisage a progression to accountable governance across all states. If attained, this would establish accountable governance as the threshold for state participation in international relations. Failure to meet the threshold would justify intrusion in the governance affairs of states by the international community of states to ensure accountability. Thus, the paper argues that the key to addressing issues of global concern lies in getting states to embrace accountable governance. This would be the first step towards empowering the international community of states to hold accountable those states that adopt governance decisions that perpetuate issues of global concern.
\end{abstract}

\section{Keywords}

state function - protection - constitutionalism - accountable governance - rule of law - separation of powers

* Senior Lecturer, Department of Law, University of Seychelles; https://orcid. org/0000-0001-5935-4653; tinashe.madebwe@gmail.com. 


\section{INTRODUCTION}

The most effective approach to addressing established issues of global concern such as violations of human rights the world, the poor quality of life in most states, and environmental deterioration throughout the world, has long been clear. ${ }^{1}$ States need to adopt approaches to governance that encourage accountability to the governed. This would ensure that decisions at state level that perpetuate common issues of global concern can be effectively challenged by all manner of actors within states prior to the issues arising. To complement this, if issues of global concern are to be addressed successfully, the international community of states should be empowered to hold states to account where they adopt governance decisions that perpetuate the occurrence of these issues.

Despite knowledge of this, states as a collective have failed to come to a mutual understanding to embrace accountable governance. The reasons for this vary. However, history suggests that failure in this regard has most prominently been attributable to states advancing arguments, and adopting the position, that their choice of approach to governance is dictated by their function. They argue that this function is informed by the needs of the people living in the state. These needs vary based on the levels of development of a state, that is, whether a state is developed, developing, or, has an economy in transition. ${ }^{2}$ Importantly, states with economies in transition and developing states

${ }^{1}$ See for example, the United Nations Charter, 1945 (UN Charter); the Universal Declaration of Human Rights, 1945 (UDHR); the International Covenant on Economic, Social, and Cultural Rights, A/RES/2200 (ICESCR); the International Covenant on Civil and Political Rights, UNTS, vol. 999, p. 171; the Marrakesh Agreement Establishing the World Trade Organization, (Annex 1A), 1867 U.N.T.S. 187; and the United Nations Framework Convention on Climate Change: resolution / adopted by the General Assembly (A/RES/48/189); the Millennium Development Goals Report 2011, ISBN 978-92-1-101244-6; the UN High Commissioner for Refugees (UNHCR), The Sustainable Development Goals and Addressing Statelessness, March 2017, available at: https://www.refworld. org/docid/58b6e3364.html [last accessed 16 May 2021].

${ }^{2}$ United Nations, "Country Classification Data Sources, Country Classifications and Aggregation Methodology", available at: https://www.un.org/en/development/ desa/policy/wesp/wesp_current/2014wesp_country_classification.pdf [last accessed 16 May 2021]. 
make up the bulk of states in the world. They commonly argue that the function of developed states can justifiably centre on the advancement of the quality of life of people living in their territories because they are already developed. Turning to accountable governance in developed states therefore makes sense because people demand this as a tool for holding the state to account where it fails to fulfil its function. Conversely, the same states with economies in transition, and developing states, argue that, since they are not developed to the level of developed states, their function is less centred on securing an enhanced quality of life for their people. Instead, their function centres more on securing the basic protection of their people. Realizing this function requires these states to place less of a premium on accountable governance and more on securing the protection of people's civil and political liberties. ${ }^{3}$ Such reasoning has made it virtually impossible to get sovereign states, looking to execute their divergent varied functions which are determined by the needs of people in their jurisdictions, to accept a universal turn to accountable governance. ${ }^{4}$ In this context, it has been equally impossible to empower the international community of states to hold sovereign states, purporting to act in furtherance of their people's interests, to account where their approaches to governance lead to the adoption of governance decisions that perpetuate the occurrence of issues of global concern. ${ }^{5}$

It is against this backdrop that this paper relies on comparative analyses of the experiences of developed states, states with economies in transition, and developing states, to make three arguments. First, the paper argues that in the modern world there has been an evolution in the state function. It highlights that a sufficient number of states at different levels of development have embraced the fact that their function is the holistic protection of people, headlined by improvement

${ }^{3}$ See an interesting review in L. Schoemann, The utilization of public-private partnerships: Fiscal responsibility and options to develop intervention strategies for HIV/AIDS in South Africa, UP Press, 2007, available at: https://repository.up.ac.za/bitstream/handle/2263/25854/Complete.pdf?sequence=11\&isAllowed=y [last accessed 16 May 2021].

${ }_{4}^{4}$ This is the experience when looking to make laws or give effect in laws in note 1.

${ }^{5}$ See Article 2 of the UN Charter. See too, Principle 21 of the UN General Assembly, United Nations Conference on the Human Environment, 15 December 1972, A/RES/2994, available at: https://www.refworld.org/docid/3b00f1c840.html [accessed 27 May 2021]. 
of people's quality of life. Second, the paper analyzes governance theory and experiences across states. Based on this, it argues that evolution and convergence in state function mean that fulfilling the state function in the modern world depends on accountable governance. This is attained where governance is based on constitutionalism realised through the rule of law and separation of powers. In this context, a state looking to fully participate in the international community should govern accountably. By that logic, a state not adopting accountable governance would offend the international order, justifying intrusions in the state's governance affairs by the international community of states to compel the state to govern accountably. Third, the paper argues that issues of global concern typically arise where there is limited commitment to accountable governance in states. As such, evolution and convergence in state function mean that the international community of states could be empowered to hold states to account where they adopt governance decisions that frustrate efforts to combat issues of global concern.

\section{THE FUnCTION OF STATES}

It has always been difficult to determine, in a general and sweeping fashion, the function of states. ${ }^{6}$ This is mostly because the state function has long depended on the history of a state and on the levels of development of a state. As such, it is hardly surprising that theorists who have delved into the state function have always offered different accounts of what the state function is. ${ }^{7}$ Importantly for the present

${ }^{6}$ R.L. Carneiro, "A theory of the origin of the state", Science, 1970, Issue 1, p. 733; A. Wimmera, Y Feinstein "The rise of the nation-state throughout the world, 1816 to 2001", American Sociological Review, Issue 7, 2010, p. 764; H. Spruyt, “The origins, development, and possible decline of the modern state", Annual Review of Political Science, Issue 1, 2002, p. 127; R. Blanco, "The modern state in Western Europe: Three narratives of its formation", Revista Debates, 2013, Issue 1, p. 169; M.J.C. Crespo, and N. Echart "The role and functions of government public relations. Lessons from public perceptions of government", Central European Journal of Communication, 2011, Issue 1, p. 109.

7 Schoemann, supra note 3. P. Schumaker, D.C Kiel, T.W Heilke, Great ideas/Grand schemes: Political Ideologies in the Nineteenth and Twentieth Centuries, McGraw-Hill, 1996; F. Cloete, H. Wissink, Improving Public Policy, Van Schaik, 2000; M.C. Needler, Identity, Interest and Ideology: An Introduction to Politics, Westport, 1996; C.J. Keulder, Trends in the 
purpose, when some of the more seminal theories on state function are considered alongside what states at different levels of development accept as being their function when they get together to make international law, it is possible to determine what states claim to be their function at the international level. When this is considered in concert with how states at different levels of development act within their own jurisdictions, it is possible to determine what the state function is in the modern world.

\section{The State Function In TheORY AND INTERnational LAW-MAKING}

When theorists' varied accounts on what the state function is ${ }^{8}$ are read in conjunction with analyses of how states at different levels of development have acted when they have got together to make international law, it is possible to determine that there have historically been three main internal and external state functions.

First, early theorising on the state function centred on the external function of the state as protection of the person from the threat to life and property. ${ }^{9}$ Most notably, 'social contract' theories argued that states emerged because people acquiesced to ceding their autonomy to a sovereign power, often a monarch or an aristocrat. This sovereign would establish a state. The function of states in this context was to protect people from roving banditry. ${ }^{10}$ John Locke for example, argued that free individuals were the basis for a stable society and therefore, the state function was to protect the inherent rights of individuals. ${ }^{11}$ This sort of approach to the state function has also been adopted under

Modern World-economy and Democratization in Peripheral States, HSRC Publishers, 1996; S.T. Bruyn, "The Moral Economy", Review of Social Economy, 1999, Issue 57, p. 25.

${ }^{8}$ Schoemann, supra note 3.

9 Schumaker, supra note 7; Cloete, supra note 7. Needler, supra note 5. Keulder, supra note 7 . Bruyn, supra note 7.

${ }^{10}$ Carneiro, supra note 6, p. 733; Wimmera, supra note 6, p. 764; Spruyt, supra note 6, p. 127; Blanco, supra note 6, p. 169.

${ }^{11}$ National Democratic Institute for International Affairs "Manual on Political Party Identity and Ideology", available at: https://www.ndi.org/sites/default/files/2321_identitymanual_engpdf_06032008.pdf [last accessed 16 May 2021]. 
the 'managerial' perspective which posits that states emerged due to the efforts of charismatic figures intent on tending and increasing their possessions. These figures instilled the fear of anarchy that would accompany roving banditry in local populations and got them to accept subservience to state structures. ${ }^{12}$ Once the fear took hold, these figures persuaded local populations to accept and value the existence of a centrally controlled framework of rule and develop a sense of translocal commonality and then offer these populations the option of ceding their autonomy to a sovereign. ${ }^{13}$ In terms of this perspective therefore, the function of the sovereign, and thus the state, was to ensure that there was security, order, and peace so people could live safely. ${ }^{14}$ By the same token, those championing the 'military' perspective consider that states emerged when one power-holder opted to have a standing army and moved away from the old militia system which forced other powerholders to do the same. ${ }^{15}$ This led people to proactively relinquish any claim to autonomy and instead, align with power brokers. ${ }^{16}$ As such, the state emerged to keep the peace and hold the public in check. ${ }^{17}$ Again, the function of states was the protection of people from marauding invaders. ${ }^{18}$

Consistent with theory, it would appear from the conduct of states when they have got together to make international law that they have historically considered that their external function centres on the protection of people from roving banditry and organized military action. Thus, as far back as 1899 states such as Germany, AustriaHungary, Belgium, China, Denmark, Spain, the United States, Mexico, France, and the United Kingdom agreed to the Convention for the Pacific Settlement of International Disputes. The Convention looked to obviate

12 M. Olson, Power and prosperity, Basic Books, (1985).

${ }^{13}$ G. Poggi, "Theories of state formation", in K. Nash, A. Scott (eds.), The Blackwell Companion to Political Sociology Routledge, 2009, p. 97-8.

${ }^{14}$ F. D'Agostino, "Contemporary Approaches to the Social Contract", available at: https://plato.stanford.edu/entries/contractarianism-contemporary/, [last accessed 16 May 2021].

${ }_{15}$ Poggi, supra note 13, p. 95; Blanco, supra note 6, p. 169.

${ }^{16}$ Ibid.

17 Poggi, supra note 13, p. 102-106; P. Carroll, “Articulating Theories of States and State Formation", Journal of Historical Sociology, Issue 4, 2009, p. 553.

${ }_{18}$ Carroll, supra note 17, p. 553. 
as far as possible recourse to force in the relations between states and ensure the pacific settlement of international differences. ${ }^{19}$ Concern with protecting people from roving banditry and organized military action was also the inspiration behind the agreement to the Treaty of Versailles following the First World War. The Treaty, which was signed in 1919 by Germany, the United States, France, Italy, and Great Britain would lead to the creation of the League of Nations. The League was intended to promote international cooperation and to achieve peace and security. Since then, as more states have emerged, state conduct has only reaffirmed the fact that their function centres on the protection of people from roving banditry and organized military action. Thus, 152 states have signed the Genocide Convention ${ }^{20}$ which classically focuses on protecting people from roving banditry and organized military action. In addition, 146 states have also signed the Refugee Convention ${ }^{21}$ which, in Article 2 (2), provides that states have an obligation to protect people in their jurisdictions.

Secondly, throughout history, theorists have considered that once peace is attained and people are generally safe from the threat of roving banditry and organized military action, a major concern of people living in states is survival. ${ }^{22}$ Historically, the turn to industrialization led to the emergence of paid work as the most prominent way in which people looked to generate resources needed for survival, a position which stands to this day. ${ }^{23}$ Importantly for the state function, theorists argued that where people pursued paid work, there was the threat of exploitation by employers. This could lead to disgruntlement among labour which would, in turn, lead to anarchy. As such, theorists argued that once roving banditry and organized military action were no long-

191 AJIL 103 (1907).

${ }^{20}$ Convention on the Prevention and Punishment of the Crime of Genocide, United Nations, Treaty Series, vol. 78, p. 277.

21189 UNTS 137.

22 A. Szirmai, Economics and Social Development: Trends, Problems, Policies, Prentice Hall, 1997.

${ }^{23}$ S.M. De Lue, Political Thinking, Political Theory and Civil Society, Allyn and Bacon, 1997. D. Schecter, Sovereign States or Political Communities? Civil Society and Contemporary Politics, Manchester University Press, 2000; A. Heywood, Political Ideas and Concepts: An Introduction, St. Martin's Press, 1994; Bruyn, supra note 7, p. 25. 
er a primary threat, the main internal function of states was protecting people through regulating the work relationship. ${ }^{24}$

From their conduct when making international law it would appear that states have endorsed the arguments in these theories. This is most apparent from the fact that efforts at addressing the threat posed by roving banditry and organized military action have typically been accompanied by efforts to protect labour from exploitation. This most prominent occurred in 1919, following the First World War. As part of the drive to secure peace, states dedicated Part XIII of the Versailles Peace Treaty ending World War to the creation of the International Labour Organization. The need for such a progression had been made apparent by nineteenth-century labour and social movements which culminated in widespread demands for social justice and higher living standards for the world's working people. ${ }^{25}$ Similarly, in 1946 when the world was recovering from the Second World War, the Organization became the first specialized agency associated with the United Nations. Still in existence, the Organization's mandate is to advance social and economic justice through setting order for international labour standards to ensure accessible, productive, and sustainable work worldwide in conditions of freedom, equity, security, and dignity. The original membership of 45 countries in 1919 has now grown to 187 states, with all the states being at different levels of development. ${ }^{26}$

Third, theorists have argued that once protection from roving banditry, organized military action, and protection from exploitative work relations is secured, people in states typically concern themselves with living more comfortable lives. Thus, another internal function of states becomes the improvement of people's quality of life. ${ }^{27}$ Theorists

${ }_{24}$ Poggi, supra note 13, p. 102-106; Blanco, supra note 6, p. 169; P.J. Cooper, L.P. Brady, O. Hidalgo-Hardeman, A. Hyde, K.C. Naff, J.S. Ott, H. White, Public Administration for the Twenty-first Century, Harcourt Brace College Publishers, 1998.

${ }_{25}$ M.L.A. Style "International Labour Organization - History", available at: https:// www.nobelprize.org/prizes/peace/1969/labour/history/, [last accessed 1 June 2021].

${ }^{26} \mathrm{ILO}$, "History of the ILO", available at: https://www.ilo.org/global/about-the-ilo/ history/lang--en/index.htm, [last accessed 1 June 2021].

27 M. Gomez "Social Economic Rights and Human Rights Commissions", Human Rights Quarterly, 1995, Issue 17, p. 155; K. Casla, “The Importance of a Socioeconomic Rights Approach to Transitional Justice", available at: https://www.e-ir.info/2012/09/13/the-importance-of-a-socioeconomic-rights-approach-to-transitional-justice/ [last accessed 
argue that states can most prominently achieve this by protecting people's socioeconomic rights and ensuring that people enjoy the benefits that these rights bestow. ${ }^{28}$

As with other theories, it appears that states have endorsed the arguments in these theories through their actions when making international law. Thus, states embrace an obligation to advance the quality of life through rights. For instance, 193 of the 195 states in the world have ratified the United Nations Charter. ${ }^{29}$ By doing so, they have affirmed "faith in fundamental human rights, in the dignity and worth of the human person, in the equal rights of men and women and of nations large and small, and...to promote social progress and better standards of life in larger freedom." In Article 56 of the Charter states pledged themselves to "take joint and separate action...for the achievement of, inter alia, higher standards of living, full employment, and conditions of economic and social progress and development; and, universal respect for, and observance of, human rights and fundamental freedoms for all without distinction as to race, sex, language, or religion." In complement to this, 150 states have affirmed, through the 1948 Universal Declaration of Human Rights (UDHR), ${ }^{30}$ their faith in, inter alia, the equal rights of men and women and have determined to promote social progress and better standards of life in larger freedom. ${ }^{31}$ This commitment to quality of life concerns can also be inferred from the fact that some the most ratified treaties in the world are: the Vienna Convention for the Protection of the Ozone Layer ${ }^{32}$ and its Montreal Protocol on Substances that Deplete the Ozone Layer ${ }^{33}$ which, provided frameworks for international reductions in the production of chlorofluorocarbons, because of their contribution to the destruction of the ozone layer, in order to protect people's health and lives; the United Nations Framework Convention on Climate Change ${ }^{34}$

1 June 2021]. D. Ahmed and E. Bulmer," Social and Economic Rights, International IDEA Constitution-Building Primer 9", available at: https://www.idea.int/sites/default/files/ publications/social-and-economic-rights-primer.pdf, [last accessed 1 June 2021].

${ }^{28}$ Gomez, supra note 27, p. 155; Casla, supra note 27; Ahmed, supra note 27.

291 UNTS XVI. See Articles 1 and 2 of the Charter.

30 The United Nations 1948.

31 See the Preamble to the UDHR.

321513 UNTS 293.

3332 ILM 874.

${ }^{34}$ A/RES/48/189. 
which, seeks the stabilization of greenhouse gas concentrations in the atmosphere at a level that would prevent dangerous anthropogenic human-induced interference with the earth's climate system so as to preserve the planet; and the United Nations Convention to Combat Desertification in Those Countries Experiencing Serious Drought and/ or Desertification, ${ }^{35}$ which aims to combat desertification and mitigate the effects of drought through national action programmes that incorporate long-term strategies supported by international cooperation and partnership arrangements. Importantly though, the conduct of states in international law-making does not necessarily point to their embracing this function to protect socioeconomic rights. For instance, in Article 22 of the UDHR, states accept that everyone, as a member of society, has the right to social security and is entitled to realization of the economic, social, and cultural rights indispensable for his dignity and the free development of his/her personality. Similarly, in Article 2 (1) of the International Covenant on Economic, Social, and Cultural Rights (ICESCR), states undertook to take steps to progressively achieve the full realization of the economic, social, and cultural rights recognized in the Covenant. In both instances however, states qualified the obligation on them to ensure that people enjoyed the benefits that these rights bestow on people based on the availability of resources. It is clear then that at the international level states do not accept that it is their function to improve the quality of life unless they have resources to devote to this.

Thus, throughout history there have been three main state functions on which theorists and states have agreed. The most primary external function, particularly for emerging states, is the protection of people from roving banditry. Once this is relatively attained, an internal state function is the protection of labour from exploitation. Attainment of this leaves states with the corollary internal function of improving people's quality of life. Importantly, there are few states that are still emerging. In addition, while effecting protections of the labour framework may be problematic, it is true that there are frameworks in place to secure such protections. By that logic therefore, the main function of states in the modern world should be the improvement of people's quality of life. ${ }^{36}$

3533 ILM 1328 (1994).

${ }^{36}$ D. Bilchitz, "Socio-economic rights, Economic Crisis, and Legal Doctrine", International Journal of Constitutional Law, 2014, p. 710-739. 
However, states are ambivalent about the last function when making international law. As such, it is useful to get clarity on how states perceive this function based on an analysis of their conduct within their jurisdictions.

\section{Discerning Perceptions of State Function FROM THE ACTIONS OF STATES IN THEIR JURISDICTIONS}

An analysis informed by the conduct of developed states, states with economies in transition, and developing states, highlights three consistencies in how states act regardless of their level of development. These consistencies in conduct offer greater insights into the extent to which states regard improving the quality of life of people in their jurisdictions as a central function, than what can be inferred from state conduct when making international law.

First, one of the dominant ways in which the legitimacy of most states at different levels of development is secured is through the election system. This process relies heavily on political manifestos drafted by politicians who subsequently assume office. ${ }^{37}$ These manifestos have been described as "strategic documents written by politically sophisticated party elites with many different objectives in mind." ${ }^{38}$ Of note, politicians make these proclamations despite knowing that there is no legal obligation on them to deliver on these promises. ${ }^{39}$ As such, manifestos are reflective of what the politicians, who will be central figures in the state, recognise as being the function of the state based on what people expect. ${ }^{40}$ Thus, it is telling that across states at different levels of development, manifestos reflect an acceptance that the state

37 I. Budge, “The Internal Analysis of Election Programs", in I. Budge, D. Robertson, D. Hearl, (eds.), Ideology, Strategy and Party Change: Spatial Analyses of Postwar Election Programmes in 19 Democracies, Cambridge University Press, 1987, p. 18.

${ }_{38}$ M. Laver, J. Garry, "Estimating Policy Positions from Political Texts", American Journal of Political Science, 2000, Issue 44, p. 619.

39 S. Brouard, E. Grossman, I. Guinaudeau, S. Persico, C. Froio, “Do Party Manifestos Matter in Policy-Making? Capacities, Incentives and Outcomes of Electoral Programmes in France", Political Studies, 2018, Issue 66, p. 1.

${ }^{40}$ Budge, supra note 37, p. 18; L. Mansergh, "Do Parties Make a Difference? A Comparison of Party and Coalition Policy in Ireland using Expert Coding and Computerised 
function is securing the holistic protection of people, headlined by improvement of the quality of life. ${ }^{41}$ For instance, the winning party's manifesto in the United Kingdom, a developed state, promised that the state would invest every week in science, schools, apprenticeships, and infrastructure, fund the National Health Service, and not raise the rate of income tax, value added tax, or National Insurance. ${ }^{42}$ Similarly, the winning party's manifesto in South Africa, a state with an economy in transition, centred on "creating new and decent jobs, transforming the economy to serve all people, ensuring universal access to quality health care, providing comprehensive social security, and building safer communities." ${ }^{\prime 3}$ Separately, the winning party's manifesto in Zimbabwe, a developing state, promised in the relevant part to rehabilitate and establish at least one vocational training centre per administrative district, establish at least one new hospital per administrative district by 2023 , and ensure consistent economic growth of at least $6 \%$ per annum for the period 2018-2023. ${ }^{44}$ Clearly, the manifestos of states at different levels of development consistently carry promises to, inter alia, secure economic development, access to education, access to health care, access to welfare, access to transport and infrastructure, and ensure that people live in a clean environment. As such, the manifestos reflect that the politicians who end up in power appreciate that the function of states is securing the holistic protection of people, headlined by improvement of the quality of life. ${ }^{45}$

Content", available at: <https://ecpr.eu/Filestore/PaperProposal/f5bdecc6-f4b0-46c588d4-c1043b560852.pdf> [last accessed 10 May 2021].

${ }^{41}$ Crespo and Echart, supra note 6, p. 111-113.

42 Conservatives, "Our Plan: Conservative Manifesto", available at: https://www. conservatives.com/our-plan, [last accessed 1 June 2021].

43 ANC, "2019 ANC Election Manifesto Summary Let's Grow South Africa Together", available at: https://voteanc.org.za/assets/manifesto-summaries/A5_Manifesto_English.pdf, [last accessed 10 May 2021].

44 ZANU PF, "The 2018 Election Promises - ZANU PF Manifesto", available at: https://zimfact.org/the-2018-election-promises-zanu-pf-manifesto/ [last accessed 1 June 2021].

${ }^{45}$ R. Pogorelis, B. Maddens, W. Swenden, “Issue Salience in Regional and National Party Manifestos in the UK", West European Politics, 2005, Issue 28, p. 992-1014. 
Secondly, a consistent theme across states at different levels of development is the justifications for taxing the public. ${ }^{46}$ Generally, states at all levels of development look to ensure that taxation is seen as legitimate by the people expected to pay the taxes. ${ }^{47}$ For this reason, tax regimes in such varied states as the United Kingdom, ${ }^{48}$ South Africa, ${ }^{49}$ and Zimbabwe ${ }^{50}$ are rooted in legislation made by the people's representatives. ${ }^{51}$ Consistencies can be found in the justifications proffered for such legislation in different states. For instance, in the United Kingdom, the justification for taxation is, inter alia, to pay for the country's defence services, its health, welfare and social services, its schools and universities, transport systems, industry, sport, heritage, and culture. ${ }^{52}$ Separately, in South Africa taxation is justified on the grounds that it pays for education, social welfare, health, housing, and economic development. ${ }^{53}$ By the same token, the justification for taxes in Zimbabwe is attached to such things as combating climate change and building resources to respond to health threats such as the threat posed by

46 T. Besley, T. Persson, "Why do Developing Countries Tax So Little?", Journal of Economic Perspectives, 2014, Issue 28, p. 99; T. Besley, T. Persson, “The Causes and Consequences of Development Clusters: State Capacity, Peace and Income", Annual Review of Economics, 2014, Issue 6, p. 927.

${ }^{47}$ M.E. Kornhauser, "Legitimacy and the Right of Revolution: The Role of Tax Protests and Anti-Tax Rhetoric in America", Buffalo Law Review, Issue 50, p. 819 (2002).

${ }^{48}$ UK Legislation, available at: https://www.legislation.gov.uk/uksi/2020/incometax, [last accessed 1 June 2021].

${ }^{49}$ Income Tax Act 58 of 1962.

${ }^{50}$ Income Tax Act [Chapter 23:06]

${ }^{51}$ ECPR, “Taxation and Legitimate Rule", https://ecpr.eu/Events/Event/PanelDetails/848, [last accessed 1 June 2021].

F. Boräng, A. Persson, E. Tengs, “The Fiscal Contract Revisited: How Taxation by Weak and Patronage-Based States Shapes Citizens: Demand for Public Goods and Democratic Inclusion", available at: https://ecpr.eu/Events/Event/PaperDetails/48587, [last accessed 1 June 2021].

52 UK Parliament, “Why Taxes?”, available at: https://www.parliament.uk/about/ living-heritage/transformingsociety/private-lives/taxation/overview/incometax/, [last accessed 1 June 2021]; S. Adam, J. Browne, C. Heady, "Taxation in the UK", available at: https://www.ifs.org.uk/uploads/mirrleesreview/dimensions/ch1.pdf, [last accessed 1 June 2021].

53 "Government Spending and Income", available at: https://www.etu.org.za/toolbox/docs/development/income.pdf, [last accessed 1 June 2021]. 
HIV/AIDS. ${ }^{54}$ This is reflective of the justifications for taxation in states throughout the world, which include, the construction of roads and bridges, schools, health facilities and the provision of social services such as the provision of salaries for civil servants including the police, the army, judges, doctors, nurses, and teachers. ${ }^{55}$ Clearly, the approach to extracting taxes by states at different levels of development reflects that, at the national level, states embrace that their function is securing the holistic protection of people, headlined by improvement of the quality of life. ${ }^{56}$

Thirdly, a consistent theme throughout states at different levels of development is their approach to justifying planned, unplanned, voluntary, or, coerced, relocation of communities. ${ }^{57}$ For instance, the United

${ }^{54}$ Atmospheric Pollution Control Regulations, Statutory Instrument 72 of 2009. D. Tonderayi, "Combating Greenhouse Gas Emissions in a Developing Country: A Conceptualization and Implementation of Carbon Tax in Zimbabwe", Journal of Social Development in Africa, 2012, Issue 27, p. 163; National AIDS Council of Zimbabwe Act, Chapter 15:14; N. Bhat, P.H. Kilmarx, F. Dube, A. Manenji, M. Dube, T. Magure, “Zimbabwe's National AIDS Levy: A Case Study", Journal of Social Aspects of HIV/AIDS, 2016, Issue 13, p. 1-7.

55 M. Weber, "Politics as a Vocation", in H.H. Garth, C. Wright Mills, (eds.), Essays in Sociology, Macmillan, 1946; Carneiro, supra note 6, p. 733-8; Olson, supra note 12; J.R. Strayer, On the Medieval Origins of the Modern State, Princeton Classics, 1970, p. 26. R. Sanchez de la Sierra, "On the Origins of the State: Stationary Bandits and Taxation in Eastern Congo", available at: https://voxeu.org/article/stationary-bandits-taxation-and-emergence-states, [last accessed 10 May 2021]; M.S. Cox, C.E. McLure, "Taxation", available at: https://www.britannica.com/topic/taxation/Shifting-and-incidence, [last accessed 10 May 2021]; OECD, "Addressing the Tax Challenges of the Digital Economy", available at: https://www.oecd.org/tax/addressing-the-tax-challenges-of-thedigital-economy-action-1-2015-final-report-9789264241046-en.htm, [last accessed 10 May 2021]; F.N. Judson, "Public Purposes for Which Taxation Is Justifiable", The Yale Law Journal, 1908, Issue 17, p. 162-169.

56 Besley, supra note 46, p. 99; C. Tilly, “War Making and State Making as Organized Crime", in P. Evans, D. Rueschemeyer, T. Skocpol, (eds.), Bringing the State Back In, Cambridge University Press, 1985; Judson, supra note 55, p. 169; Pogorelis, supra note 45, p. 28.

57 R.V. Hagen, T. Minter, "Displacement in the Name of Development: How Indigenous Rights Legislation Fails to Protect Philippine Hunter-Gatherers", Society and Natural Resources, 2020, Issue 33, p. 65; T. Minter, V. de Brabander, J. van der Ploeg, G. Persoon, "Whose Consent? Hunter-gatherers and Extractive Industries in the North-eastern Philippines", Society and Natural Resources, 2012, Issue 25, p. 1241; M.L. Walls, L.B. Whitbeck, "The Intergenerational Effects of Relocation Policies on Indigenous Families", Family Issues, 2012, Issue 33, p. 1272-1293; J. Herbst, States and Power in Africa: Comparative Les- 
Kingdom justified approving the building of a third runway at Heathrow airport on the grounds that the expansion would create jobs and have a positive impact on the British economy by ensuring that businesses would not move out of London and the United Kingdom. ${ }^{58}$ Separately, when it forcibly relocated people from the Johannesburg township of Alexandra in 2001, South Africa's Gauteng provincial government argued that their removal was a means of helping those neglected by successive white minority governments and creating a healthy environment in which residents would be spared risks from cholera and flooding. ${ }^{59}$ Separately, during Zimbabwe's 'Operation Murambatsvina' when street vendors, tuck-shop owners and small-business operators were displaced from urban centres, the state justified this displacement on the basis that this would remove health hazards, the threat of crime, and reduce levels of violence. ${ }^{60}$ From these justifications it is apparent that states at different levels of development embrace that their function

sons in Authority and Control, Princeton University Press, 2002; M. Cernea, "The Risks and Reconstruction Model for Resettling Displaced Populations", World Development, 1997, Issue 25, p. 1569; M. Cernea, "Risks, Safeguards and Reconstruction: A Model for Population Displacement and Resettlement", Economic and Political Weekly, 2000, Issue 35, p. 3659; C. Stephens, "The Indigenous Experience of Urbanization", in P. Grant, State of the World's Minorities, Minority Rights Watch International, 2015; United Nations Office of the Commissioner for Human Rights, "States Must Act Now to Protect Indigenous Peoples During Migration", available at: https://www.ohchr.org/EN/NewsEvents/Pages/ DisplayNews.aspx?NewsID=23429\&LangID=E [last accessed 10 January 2021]; E.A. Daes, "Prevention of Discrimination and Protection of Indigenous Peoples and Minorities: Indigenous peoples and their Relationship to Land", available at: https://www.refworld.org/docid/3b00f23621.html, [last accessed 10 January 2021; J. Carino, D. Champagne, N. Collings, M. Cunningham, D.S. Dorough, N. Kipuri, M. Trask, "The State of the World's Indigenous Peoples", available at: https://www.un.org/esa/socdev/unpfii/ documents/SOWIP/en/SOWIP_web.pdf, [last accessed 10 January 2021]; B. Terminski, "Oil-induced Displacement and Resettlement: Social Problem and Human Rights Issue", available at: https://www.files.ethz.ch/isn/156127/1c56976ceb4f8e825e294e5268469185. pdf [last accessed 1 June 2021].

58 S. Deneulin, L. Shahani, An Introduction to the Human Development and Capability Approach: Freedom and Agency, Earthscan, 2009, p. 11.

${ }_{59}$ M. Ramutsindela, "Forced removals in South Africa: A Thing of the Past?", available at: https://www.fmreview.org/sites/fmr/files/FMRdownloads/en/researching-internal-displacement/ramutsindela.pdf, [last accessed 1 June 2021].

60 A. Hammar, "Reflections on Displacement in Zimbabwe", Bulletin, 2008, Issue 80, p. 28. 
is securing the holistic protection of people, headlined by the improvement of the quality of life. ${ }^{61}$

Effectively, the conduct of states within their jurisdictions points to the fact that states have recognized that their continued existence depends on what people think. These opinions are shaped by people's trust of the state, leadership of those in command, and the state performance. ${ }^{62}$ In this context, the function of a successful state is the holistic protection of the people headlined by improvement of the quality of life. Granted, the states which are relied on to make this argument make up a small sample size. In addition, it is to be expected that there will be developed states, states with economies in transition, and developing states in which the same issues are addressed differently. Despite all this, the practices of a sufficient enough number of states at different levels of development are informative. They establish that states often dispute that their function is the holistic protection of people headlined by improvement of the quality of life when they make international law. However, their conduct within their jurisdictions generally points to the fact that they embrace this as their function.

\section{AddREsSing ISSUES OF Global CONCERN}

Insofar as addressing issues of global concern is concerned, the fact that there has been clear evolution and convergence in state function is significant for two reasons.

\section{AcCountable GovernanCE}

Governance theory suggests that the holistic protection of people, headlined by improvement of the quality of life, is attainable when people

${ }^{61}$ J. Woodburn, "Indigenous Discrimination: The Ideological Basis for Local Discrimination Against Hunter-Gatherer Minorities in Sub-Saharan Africa", Ethnic and Racial Studies, 1997, Issue 20, p. 345; Hagen, supra note 57, p. 65-82; Stephens, supra note 57; Y. Nesterova, "Indigenous Peoples: Key Trends that Affect their Development", available at: https://impakter.com/indigenous-peoples-part-two/, [last accessed 10 January 2021].

${ }^{62}$ Crespo and Echart, supra note 6, p. 110. 
can hold the state to account for failure to deliver on this function. Such accountability can obviously be secured in different ways. However, an appraisal of relevant theories suggests that holding the state to account can most effectively be secured through governance based on constitutionalism. ${ }^{63}$ This is because "constitutionalism suggests the limitation of power, the separation of powers and the doctrine of accountable responsible government." ${ }^{64}$

In practical terms, governance based on constitutionalism is attained when there is commitment to the rule of law. ${ }^{65}$ Lord Bingham, a most notable scholar on the rule of law, noted that persons and authorities within the state, whether public or private, should be bound by and entitled to the benefit of laws publicly made, taking effect (generally) in the future and publicly administered in the courts. ${ }^{66} \mathrm{He}$ considered further, that the law must be accessible and so far as possible intelligible, clear, and predictable; questions of legal right and liability should ordinarily be resolved by application of the law and not the exercise of discretion; the laws of the land should apply equally to all, save to the extent that objective differences justify differentiation. ${ }^{67}$ Here, it is also interesting to consider Dicey's conception of the rule of law in which he argued that the rule of law is attained where: there is no punishment inflicted other than for a breach of the law; that irrespective of rank or status all are equal under the law; and, that rights and freedoms are

${ }_{63}$ M. Ryan, Unlocking Constitutional and Administrative Law, 2nd ed., Routledge, p. 15, 60-92; E. Petersmann, "How to Reform the UN System? Constitutionalism, International Law and International Organizations", Leiden Journal of International Law, 1997, Issue 10, p. 421, 426-428; M. Bazezew, “Constitutionalism”, Mizan Law Review, 2009, Issue 3, p. 358; H. Barnett, Constitutional and Administrative Law, 3edn., Cavendish Publishing Limited, 1995, p. 5-6.

${ }^{64}$ Barnett, supra note 63, p. 6, 63; Bazezew, supra note 63, p. 358.

65 See however, Ryan, supra note 63, p. 11. M. Rosenfeld, “The Rule of Law and the Legitimacy of Constitutional Democracy", Southern California Law Review, 2001, Issue 1, p. 1309; E. Petersmann, "How to Constitutionalize International Law and Foreign Policy for the Benefit of Civil Society?", Michigan Journal of International Law, 1998, Issue 20, p. 1, 13, 17; S.B. Prakash, J.C. Yoo, "The Origins of Judicial Review”, The University of Chicago Law Review, 2003, p. 70887.

66 T. Bingham, The Rule of Law, Allen Lane, 2010.

${ }^{67}$ Ibid. 
best protected under the common law. ${ }^{68}$ Drawing from these and other conceptions of the rule of law, the critique levelled against theories, as well as experience with governance in states at different levels of development, it is useful to highlight that the rule of law is realized where everyone is equal before the law, decisions are not made in an arbitrary manner, and, people have access to the courts.

Importantly, the fact that the rule of law is realized where people are equal before the law makes the availability of high-quality laws critical. Raz argues that laws should ideally be: prospective rather than retroactive; open and clear; stable; and made in a procedurally correct way. As such, a key way in which to ensure that there is accountable governance based on constitutionalism is to empower a legislature to formulate well drafted laws as and when these are needed. ${ }^{69}$ Consistent with the elements of the rule of law, such laws should not empower any actors to act in an arbitrary manner. In addition, opportunities for arbitrary decision-making are limited where those acting based on the law are not involved in law-making. As such, a central element of realising the rule of law is establishing an executive body tasked with a policy-making role. Bingham argued, those who constitute the executive should exercise the powers conferred on them reasonably, in good faith, fairly, for the purpose for which the powers were conferred, without exceeding the limits of such powers and not unreasonably. Finally, it is useful to account for the fact that the legislature and the executive may be unable, or unwilling, to ensure that accountability is a feature of governance efforts. ${ }^{70}$ In such instances, realizing the rule of law will depend on people being granted access to the courts. ${ }^{71}$ According to Raz, these courts should be capable of reviewing decision making and ensuring that the principles

${ }^{68}$ P. De Vos, W. Freedman, (eds.), South African Constitutional Law in Context, Oxford University Press, 2014, p. 78; M.L. Principe, "Albert Dicey and Principles of the Rule of Law: Is Justice Blind? A Comparative Analysis of the United States and Great Britain", Loyola of Los Angeles International and Comparative Law Review, 2000, Issue 22, p. 359.

${ }^{69}$ J. Raz, The Authority of Law: Essays on Law and Morality, Oxford University Press, 1979. See however, M. Mcilwaine, "Denying Human Rights, Upholding the Rule of Law: A Critique of Joseph Raz's Approach to the Rule of Law," The Western Australian Jurist, 2016, Issue 7, p. 399.

70 Bingham, supra note, 66.

${ }^{71}$ Petersmann, supra note 63, p. 425. 
of natural justice are observed..$^{72}$ By this logic, realizing the rule of law is possible through a separation of powers.

In sum, evolution and convergence in the state function mean that governance in states at different levels of development should be based on constitutionalism. The way in which a state chooses to do this need not assume any dedicated form. What matters is that governance should be based on the rule of law, attained practically through the separation of powers.

\section{THE ROLE OF THE INTERNATIONAL COMMUNITY}

Convergence on the function of states has led to governance based on constitutionalism emerging as the minimum threshold for governance in any state. This has led to states at all levels of development adopting laws that preclude them from acting in ways that offend the international order. ${ }^{73}$ There is also a record of states at all levels of development accepting the exclusion of participation in international affairs of states that offend the international order. ${ }^{74}$ Indeed, a mix of states at different levels of development, such as Germany, Belgium, Denmark, the United States, France, the United Kingdom, Brazil, India, China, Zimbabwe, and Kenya, agreed, in Article 2 (5) of the UN Charter that "All Members shall give the United Nations every assistance in any action it takes in accordance with the present Charter, and shall refrain from giving assistance to any state against which the United Nations is taking preventive or enforcement action." As a complement to this, all these states ratified Article 5 of the UN Charter which provides that "A Member of the United Nations against which preventive or enforcement action has been taken by the Security Council may be suspended from the exercise of the rights and privileges of membership by the General Assembly upon the recommendation of the Security Council. The exercise of these rights and privileges may be restored by the Security Council. In addition, this is true where there are crimes against humanity." Similarly, in

72 Raz, supra note 69; Mcilwaine, supra note 69, p. 399.

${ }^{73}$ See for instance, the Rome Statute of the International Criminal Court (last amended 2010), ISBN No. 92-9227-227-6.

${ }^{74}$ See Chapter II of the UN Charter. 
the ozone protection effort, the same states assented to the inclusion of Article 4 (5) in the Montreal Protocol which provides that "Each Party shall discourage the export, to any State not party to this Protocol, of technology for producing and for utilizing controlled substances." Further, Article 4 (6) provides that "each Party shall refrain from providing new subsidies, aid, credits, guarantees, or insurance programmes for the export to States not party to this Protocol of products, equipment, plants or technology that would facilitate the production of controlled substances."

Most issues of global concern are perpetuated because of limited accountable governance at state level. Further, most governance decisions that perpetuate issues of global concern are rooted in non-accountable governance. This is significant. If accountable governance based on constitutionalism is established as the threshold for participation in the international community, failure to act accordingly offends the international order. The discussion above highlights that offending the international order would be grounds for suspension or exclusion from participation in the international community. Effectively, turning to accountable governance based on constitutionalism would be the first step to empowering the international community of states to hold states to account where they adopt governance decisions that frustrate efforts to combat issues of global concern.

\section{CONCLUSIONS}

It has historically been difficult to address issues of global concern. This is because states resist turning to accountable governance at state level. States also refuse to empower the international community of states to hold them to account where they adopt governance decisions that perpetuate these issues of global concern. This paper has argued that there has been an evolution and convergence in the state function. In theory, this makes it possible to motivate states to embrace accountable governance based on the fact that states have embraced the fact that their function has evolved within their jurisdictions. This would be the first step in empowering the international community of states to hold states accountable where they adopt governance decisions that perpetuate 
these issues of global concern. Therefore, the key to addressing issues of global concern lies in compelling states to accept the turn to accountable governance as a global standard and, following from this, empowering the international community of states to hold states accountable where they adopt governance decisions that perpetuate these issues of global concern.

A most important consideration in bringing this discussion to a close, is the feasibility of getting states to embrace the evolution in their function on a global level and getting them to empower the international community of states to hold states to account where they adopt governance decisions that perpetuate these issues of global concern. Here, it is worth reiterating that the conduct of states at different levels of development within their jurisdictions already points to states embracing this function. In addition, states seemingly accept that realizing this function is best done through governance based on constitutionalism, which is attained through the rule of law realised through the separation of powers. For instance, in the United Kingdom, the Constitutional Reform Act of 2005 imposes an obligation on the Lord Chancellor to uphold and ensure the rule of law. In addition, the same Act significantly enhanced the separation of powers in the United Kingdom. Separately, the South African Constitution provides, in Section 1 (c), that The Republic of South Africa is one, sovereign, democratic state founded on Supremacy of the constitution and the rule of law. The same Constitution also separates power between the executive, the legislature, and the judiciary. ${ }^{75}$ In Zimbabwe the state commitment to the rule of law is encapsulated in section 3 (1) (b) of the Constitution which provides that the country is founded on respect for the rule of law. Section 3 (2) (e) provides further that the "principles of good governance, which bind the State and all institutions and agencies of government at every level, include...observance of the principle of separation of powers." Certainly, not all states adopt this approach and achieve accountable governance. However, a sufficient enough number of states claim to aspire to achieving this manner of governance. Their failure to do so is often rooted in inadequate commitment to realising accountable governance by state ac-

75 See generally, P.N. Langa, "The Separation of Powers in the South African Constitution", South African Journal on Human Rights, 2006, Issue 22, p. 2-9. 
tors, and not an inability to appreciate the need for accountable governance and how best to secure it.

In the light of this reality, what is required in order to secure progression to effectively addressing issues of global concern is for a network of norm entrepreneurs to drive the commitment to accountable governance in states in a trans-national manner and at the international level. Ideally, this network would be composed of individuals, states, and civil society invested in seeing the accountable governance norm established. ${ }^{76}$ It is helpful that there are already influential developed states, such as the United Kingdom, and regionally influential states with economies in transition, such as South Africa, that have been involved in promoting the turn to accountable governance and greater efforts to heighten the quality of life in states. ${ }^{77}$ These states can be actively involved in entrepreneurial efforts to compel the turn to accountable governance. Separately, it is also helpful that major international money lenders, headlined by the Breton Woods institutions, and the World Trade Organization which influence the conduct of states with economies in transition and developing states, already place a premium on governance in their clients assuming a certain form. ${ }^{78}$ The activities of

${ }^{76}$ M. Finnemore, K. Sikkink, "International Norm Dynamics and Political Change", International Organization, 1998, Issue 52, p. 887; M.E. Keck, K. Sikkink, “Activists Beyond Borders: Advocacy Networks in International Politics”, Cornell University Press, 1st edn, 1998, p. 199; H.P. Schmitz, K. Sikkink, "International Human Rights", in W. Carlsnaes, T. Risse, B.A. Simmons, (eds.), Handbook of International Relations, Sage Publications, 2007, p. 517, 522; T. Risse, K. Sikkink, “The Socialization of International Human Rights Norms into Domestic Practices: Introduction", in T. Risse, S. C. Ropp and K. Sikkink (eds.), The Power of Human Rights: International Norms and Domestic Change, Cambridge University Press, 1999, p. 15; K. Sikkink, "Human Rights, Principled Issue-Networks and Sovereignty in Latin America", International Organization, 1993, Issue 47, p. 411, 413-5; M. Finnemore, K. Sikkink, “Taking Stock: The Constructivist Research Program in International Relations and Comparative Politics", Annual Review of Political Science, 2001, Issue 4, p. 391, 400-2.

77 London (AFP), "G7 Pushes Solidarity to Tackle Global Threats", available at: https://www.france24.com/en/live-news/20210504-g7-pushes-solidarity-to-tackleglobal-threats [last accessed 16 May 2021].

78 The World Bank, "Governance", available at: https://www.worldbank.org/en/ topic/governance/overview\#2, [last accessed 16 May 2021]. International Monetary Fund, "Good Governance: The IMF's Role”, available at: https://www.imf.org/external/ pubs/ft/exrp/govern/govindex.htm, [last accessed 16 May 2021]. 
these bodies could also be harnessed as part of the entrepreneurial effort to get states to accept a commitment to accountable governance.

It is not to be expected that all states would accept this turn to accountable governance. Furthermore, even states that accept this may fail to actually secure accountable governance in practice. What matters then for norm entrepreneurs (people who drive the progression of a norm through a norm life cycle) is to get enough states to accept this commitment to accountable governance so that it would become possible to establish accountable governance as the threshold for state participation in international relations which, if not met, would justify intrusion by the international community of states into the governance affairs of sovereign states in order to ensure the move to accountable governance. Considering that issues of global concern typically arise where there is limited commitment to accountable governance in states, evolution and convergence in the state function mean that under some circumstances the international community of states would be empowered to hold states accountable where they adopt governance decisions that frustrate efforts at combating issues of global concern. 
